S. Drobyazko,

Candidate of Economic Sciences, Associate Professor,

Professor Department of Finance and Accounting,

Open University of Human Development "Ukraine", Kiiv, Ukraine

DOI: $10.32702 / 2306-6806.2019 .3 .85$

\title{
THEORETICAL PRECONDITIONS FOR IMPROVEMENT OF MANAGEMENT OF ECONOMIC SECURITY OF INSURANCE SECTOR ENTERPRISES
}

\author{
C. I. Аробязко, \\ к. е. н., доцент, професор кафедри обліку та фінансів, \\ Відкритий міжнародний університет розвитку дюдини "Україна", м. Київ
}

\section{ТЕОРЕТИЧНІ ПЕРЕАУМОВИ ВАОСКОНАЛЕННЯ УПРАВАІННЯ ЕКОНОМІЧНОЮ БЕЗПЕКОЮ ПІАПРИЕМСТВ СТРАХОВОГО СЕКТОРУ}

The paper analyzes the theoretical preconditions for improvement of management of economic security of the insurance sector enterprises. The measures for ensuring a high level of economic security of the insurance sector enterprises have been considered. The features of theoretical aspects of strategic management of economic security have been revealed: tasks, principles, strategic imperatives of development. The reasons for the need to improve the system of economic security of insurance sector enterprises as conditions of survival in global competitive markets have been analyzed. The priority role of social responsibility has been proved in order to provide economic security under the impact of globalization. The world experience regarding the interpenetration of the concepts of sustainable development and responsible investment as well as accounting models has been analyzed. The legislation of the member states of the European Union concerning the question of social responsibility with the purpose of implementation of normative and legal regulation of domestic companies has been analyzed. The drivers of the appearance of the newest accounting model have been determined, taking into account the specifics of the information requests of stakeholders. The stages of transformation of key forms of traditional accounting have been considered, taking into account social and environmental components. The determinants and principal features of the stakeholder accounting model have been studied in order to increase the validity of investment decisions. Application of the stakeholder concept will increase the corporate social responsibility of the enterprise, especially the personnel component of economic security. Also, engaging in dialogue with clients of insurance companies allows the company to prevent possible risks before launching a new insurance service, to improve its image in the society, to better understand the needs of the insurance market. The main factors that can determine the outcome of the stakeholder dialogue regarding the implementation of the improved management system of the insurance sector have been considered.

Устатті проведенедослідження теоретичних передумов вдосконалення управління економічною безпекою підприємств страхового сектору. Розглянуто заходи забезпечення високого рівня економічної безпеки підприємств Страхового сектору. Розкрито особливості теоретичних аспектів стратегічного управління економічної безпеки: завдання, принципи, стратегічні імперативи розвитку. Проаналізовані причини необхідності Удосконалення системи економічної безпеки підПриємСтв Страхового сектору як умови виживання на ГАобальних конкурентних ринках. Доведено пріоритетну роль соціальної відповідальності зметою забезпечення економічної безпеки в умовах глобалізаційних процесів. Проаналізовано світовий досвід щодо взаємопроникнення концепції сталого розвитку та відповідального інвестування і моделей обліку. Проаналізовано законодавство крайн член Свропейського Союзущодо питання соціальної відповідальності з метою імплементації нормативно-правове регулювання вітчизняних компаній. Визначено драйвери появи новітньої моделі обліку з урахуванням особливостей інформаційних запитів стейкхолдерів. Розглянуто етапи трансформації кАючових форм традиційної звітності з урахуванням соціальних та еколопічних СкАадових. Досліджено детермінанти та принципіальні ознаки Стейкхолдерської облікової моделі з метою підвищення обгрунтованості інвестиційних рішень. Застосування концепції Стейкхолдерів дозволить Підвищити корпоративнУ соціальнУ відповідальність підприємСтва, особливо 
кадрової скАадової економічної безпеки. Також проведеннядіалогу зі кАієнтами Страхових компаній дозволяє компанії запобігти можАивим ризикам перед запуском нової страхової послуги, покращити свій імідж у суспільстві, краще зрозуміти потреби страхового ринку. Розглянуто основні фактори, що можуть визначати результат, діляогу стейкхолдерів щодо запровадження Удосконаленої системи управління економічної безпеки страхового сектору.

Key words: economic security, insurance market development, stakebolder concept, social responsibility.

Ключові слова: економічна безпека, розвиток страхового ринку, кончепчіл стейкхолдерів, сочіальна відповідальність.

\section{FORMULATION OF THE PROBLEM}

It is worth mentioning that achievement of the goals and objectives of economic security management is ensured through a series of actions aimed at establishing, ensuring and maintaining the necessary level of its economic security; studying the internal and external environment and determining the most important factors and criteria that affect the level of economic security; assessment of the potential or achieved level of economic security; assessment of the adequacy of a certain level of economic security for a particular market, or consolidation of positions in the already occupied market; development, if necessary, of the ways and measures of improving economic security and implementation of these measures; analysis of changes in the factors and criteria of economic security, as well as taking measures to use own positions and the exclusion or reduction of the possible negative impact of such a change on economic security.

\section{ANALYSIS OF RECENT STUDIES AND PUBLICATIONS}

The issues of the development of the insurance markets of the world are at the center of attention of foreign scientists, such as: Alhassan A. L., \& Biekpe N. (2016), Jensen N., \& Barrett C. (2017), Lee C.C., Chang C.H., Arouri M., \& Lee C.C. (2016), Prasad V. \& Mailankody S. (2017).

Highly appreciating the scientific achievements of the mentioned authors, it is necessary to recognize the lack of development of problems of forming a model of the domestic insurance market and its development as a factor in ensuring the economic security of insurance companies.

\section{SETTING OBJECTIVES}

The purpose of the paper is to study the theoretical preconditions for improvement of management of economic security of the insurance sector enterprises.

\section{CONTRIBUTION OF THE MAIN MATERIAL}

The economic security of insurance sector companies is a complex and multifaceted category. Therefore, solving the problems associated with its provision, requires enterprises to continuously meet the main tasks, improve the principles and methods of management.

The main tasks of ensuring the economic security of the insurance sector enterprises are: analysis and assessment of the situation in the insurance market; detecting the facts of unlawful negative activity of the personnel of the enterprise and their elimination; constant study of the state of affairs of partners in business and competitors; protection of the interests of the enterprise and the rights of its employees; possession of the necessary information for the development of optimal managerial decisions on the strategy and tactics of the enterprise's economic activity.

At the microeconomic level, the main principles are the following: timely prevention of possible risks; detection and prevention of internal and external hazards; competitiveness; competence of employees in ensuring economic security; timeliness of detection of various destructive factors; rational use of material and financial resources; continuity of protection of the interests of the enterprise; coherence of actions of all structural units of the enterprise; planning; effectiveness of insurance activity.
The task of strategic management is to provide such interaction of insurance enterprises with the external environment, which will enable them to maintain the potential at the level necessary to achieve their goals and survive in the long run. In order to determine the strategy of the behavior of insurance sector enterprises and implement it, management should have an in-depth understanding of the external environment, trends in its development and the place that the company occupies in it. In doing so, the external environment is studied, first of all, in order to identify the hazards and potential opportunities that an enterprise must take into account in determining and achieving its goals.

The main criteria for assessing the reliability and effectiveness of the economic security of the insurance sector enterprises should be: ensuring the stable operation of the enterprise; saving of monetary and material values; ensuring stable profits; prevention of crisis and emergency situations; timely detection, prevention and neutralization of real and potential internal and external threats to national interests in the field of insurance.

Since the entities of the economic security of the insurance sector enterprises may be persons and structural units operating directly at the enterprise (internal entities) and organizations and officials who are not part of the enterprise (external entities), then the security of all subjects of economic security combined with business processes ensure the continuity of the technology of providing insurance services.

Management of the economic security of the insurance sector enterprises is a process of implementing the functional components of economic security in order to prevent possible losses and to achieve the maximum level of economic security now and in the future.

Activities in order to ensure the economic security of the insurance sector enterprises should include: justification of the level of acceptable risk when making managerial decisions; development of a strategy and tactics of conducting economic activity that will minimize economic risk and provide economic security; protection of material, financial, personnel and information resources of the enterprise from the possible negative effects of factors and threats.

Both external and internal risks can directly affect the volumes and quality of service delivery, as well as the change in their structure. Unlike variable costs that vary in proportion to the volume of services provided, the growth of fixed costs increases the risk of instability of the enterprise.

In this regard, it is necessary to use an integrated approach based on the theory of risks as an active position, which involves predicting future events, rather than a passive response to risk, since such an approach provides more opportunities for avoiding threats and limiting the risk of their occurrence.

The implementation of the decisions made is provided through the practical methods of risk management organization, that is through $[7 ; 8 ; 11]$ : the allocation of the main tasks and functions related to risk management, planning of measures for reducing risks, determining the forms of their financing; a rational combination of all elements of the control system: the division of tasks according to the levels of management, the formation of 
Table 1. Measures for ensuring a high level of economic security of the insurance sector enterprises

\begin{tabular}{|c|c|c|}
\hline № & $\begin{array}{c}\text { Name of the scientific } \\
\text { instrument }\end{array}$ & Measures \\
\hline 1.1 & $\begin{array}{l}\text { Creation of the Department } \\
\text { of Economic Security and its } \\
\text { implementation into the } \\
\text { organizational structure }\end{array}$ & $\begin{array}{l}\text { implementation of monitoring of the level of economic security and its components; } \\
\text { forecasting of risks and development of measures for their neutralization; adjusting } \\
\text { performance indicators in the context of providing economic security, developing a } \\
\text { system of rules and security regimes }\end{array}$ \\
\hline 1.2 & $\begin{array}{l}\text { Selection of the sector of } \\
\text { economic security within the } \\
\text { legal department }\end{array}$ & $\begin{array}{l}\text { Creating instructions on material liability and protecting trade secrets; monitoring of } \\
\text { legislation and protection of the enterprise from actions and decisions of public } \\
\text { administration bodies; management of institutional security features within legal } \\
\text { relationships with contractors; registration of documents, property rights }\end{array}$ \\
\hline 2.1 & $\begin{array}{l}\text { Operational response to } \\
\text { threats to information } \\
\text { security and dissemination of } \\
\text { negative information about } \\
\text { the enterprise }\end{array}$ & $\begin{array}{l}\text { analysis, accounting of commercial information; creation of a reliable information security } \\
\text { system and its transmission channels; use of modern information security technologies }\end{array}$ \\
\hline 3.1 & $\begin{array}{l}\text { Enhancing the effectiveness } \\
\text { of managing economic } \\
\text { security }\end{array}$ & implementation of international quality management systems at the enterprise \\
\hline 4.1 & $\begin{array}{l}\text { Increasing the economic } \\
\text { efficiency by using resources }\end{array}$ & $\begin{array}{l}\text { realization of measures directed on increase of efficiency of use of economic resources; } \\
\text { assessment of the level of modernity and productivity of material and technical base, } \\
\text { search of reserves for their improvement; increase of the profitability of assets and } \\
\text { competitiveness of the enterprise }\end{array}$ \\
\hline 4.2 & $\begin{array}{l}\text { Creation of preconditions for } \\
\text { enterprise development }\end{array}$ & \multirow[t]{2}{*}{$\begin{array}{l}\text { financing of measures for forecasting the development of a market situation, institutional } \\
\text { regulation of financial and economic activity and resource provision }\end{array}$} \\
\hline 4.3 & $\begin{array}{l}\text { Providing access to } \\
\text { resources and markets }\end{array}$ & \\
\hline 5.1 & $\begin{array}{l}\text { Increasing the level of } \\
\text { motivation in the enterprise } \\
\text { security system }\end{array}$ & $\begin{array}{l}\text { realization of measures of material stimulation; creation of an effective system of moral } \\
\text { encouragement of employees; development of behavior rules; creating an atmosphere of } \\
\text { corporate spirit }\end{array}$ \\
\hline
\end{tabular}

Source: author's development.

units (training of specialists) on risk management, the distribution of rights, responsibilities and powers to ensure effective risk management; formation of information flows and technical support for risk management.

In order to create an effective system of risk management in the insurance sector, it is necessary to put in place certain organizational efforts, to attract additional financial and other resources.

Comprehensive management of the company's economic security, ensuring a sufficiently effective system of detection and elimination of threats, are provided by the establishment of management of the system of economic security, its all functional components.

Typically, the target enterprise management subsystem includes the traditional benchmarks for its economic activity, in particular, maximizing profits and minimizing costs. How ever, the new conditions of operation of most of the companies of the XX century forced them to move away from these purely economic goals $[4 ; 5]$.

Measures are being developed within each instrument (Table 1).

For them, profit is necessary, but not sufficient in the process of life. That is, economic and financial interests go to the background, providing the necessary material development of production. On the first plan put forward questions that are related to the intangible side of the relationship between the enterprise and its environment. One of the main directions of such relations is their socialization.

Moreover, as the practice of leading companies of the beginning of the XXI century shows, the question of the socialization of economic relations concerns not only the external environment of the enterprise, but also those relations which are formed in its internal environment, in particular relations between the owners of means of production and employees. Strengthening the tendency of the socialization of economic relations manifests itself in various forms.

The social orientation of the activities of companies is, above all, a manifestation of the global tendency of socialization and humanization of economic relations.

In the business sector, this tendency is expressed in the concept of social responsibility, when companies are responsible to all people and organizations they face in the process, and to society as a whole.
The mainstream of global governance and social development is the concept of sustainable development, the benchmarks of which are formalized at the level of the United Nations Sustainable Development Goals. A communication basis for assessing progress in achieving these goals is reporting on sustainable development. The Europe 2020 Strategy and its adopted Strategy for Sustainable Development Ukraine-2020 (vector of development) are declarative documents for achieving an energy-efficient, sustainable, innovative and competitive economy and the stated objectives. One of the directions of the EU Strategy in promoting policy is corporate social responsibility is to improve the disclosure of social and environmental information that is consistent with the goals of sustainable development 12 and its target 12.6.

The adoption in 2014 of Directive 2014/95/EU on the disclosure of non-financial and diversified information by some companies and groups has obliged member states to join at the highest legislative level through the mechanisms for the disclosure of information from sustainable development to the implementation of Target 12.6 and the Europe 2020 Strategy [1].

Individual EU countries, including Great Britain, France and Denmark, are among the first to join these initiatives. For example, the Companies Act in the UK sets a requirement for disclosure of greenhouse gas emissions in an annual report. The Grenelle II Act in France requires large public and listed companies to report corporate social responsibility in an annual management report and from 2016 obliged to provide disclosure on climate change [2]. More than 1,100 largest Danish companies have to report on corporate social responsibility, especially in terms of climate change and human rights in annual reporting. The Spanish Sustainability Economy Law (2011) and the Italian Mandatory Disclosure and Investment Policy (2012) establish mandatory disclosure requirements for nonfinancial information by pension funds [3].

Consequently, at the current stage of economic development, the effectiveness of the company depends largely on the degree of its involvement in solving the global challenges facing the world community. Among such tasks, in the first place, should include the improvement of economic and social relations in society. Thus, socially active behavior directly affects the reputation of the business. This 
is confirmed by the linear relationship between the index of corporate social responsibility and the reputation of the world's leading companies, which is defined in the study "Global Reputation Pulse Study" (2010) [6].

In the process of implementation of the concept of corporate social responsibility, the behavior of companies is aimed at taking into account the interests of society, responsibility for the impact of their activities on customers, suppliers, employees, shareholders, local communities and other stakeholders, on the environment, etc. When choosing corporate social responsibility for the philosophy of their behavior, the company makes a voluntary contribution to the development of society in the social, economic and environmental spheres, which is directly related to its main activity and goes beyond the legal minimum. In modern conditions, social behavior plays an important role in creating the values that shape its economic security. Principles of realization of this direction of activity of insurance companies should be included in the target subsystem of the mechanism of economic security management.

Currently, the practice of carrying out activities spreads to ensure the economic security of the enterprise on a systematic basis. Creation and functioning of the system of economic security of the enterprise provides the possibility of reliable and continuous security of its economic activity. Attempts to provide enterprise economic security by situational measures and actions that are responses to emerging threats or potential threats are doomed to inefficiency. Therefore, it is necessary to improve the model of management of the system of economic security.

The order of transformation of key forms of traditional accounting taking into account social and environmental constituents is an intermediate step in the transition to the concept of accounting, reporting, audit in a sustainable development, with the following stages [9]:

- the determination of the impact of social and environmental-economic effects on the costs and benefits of the organization, reflected in the corresponding accounts of operating, financial and investment income and expenses, and aggregated in the statement of financial results (statement of aggregate income);

- supplementing and expanding the income and expense accounts of the report with hidden social and environmental effects, reproduction and depletion of the respective types of capital;

- taking into account the influence of hidden assets (brand, reputation, goodwill, increase in the value of human, social, intellectual capital) and liabilities (environmental externalities, losses of natural capital, associated with balance sheet items).

The conducted analysis of accounting systems and models in modern conditions makes it possible to substantiate the importance of forming a convergent stakeholder model of accounting, reporting, audit as an evolutionary continuation of an international model that takes into account the peculiarities of the global model of social and environmental reporting, but before a broader stakeholder circle. It is based on both the global standards of financial reporting and the principles of sustainable development and responsible investment.

Convergent stakeholder accounting model has the following principal features [9]:

1. Background of the appearance - integration of the principles and dimensions of sustainable development into the activities of companies in the globalized markets.

2. Stakeholders' main information needs - requests by investors, creditors to take into account the dimensions of sustainable development in the company's activities, local communities, governments, public organizations, etc.

3. Standards - 2 types: standards for disclosure of information on the environmental and social dimensions of the company's activities, aimed at forming a comprehensive picture of its activities; converged accounting, reporting, and professional standards, aimed at unifying and ensuring the transparency of the company's financial statements.

4. Prevailing reporting type - non-financial, integrated.

5. Assurance on reporting indicators.

6. Independent verification of accounting becomes an integral part of the reporting and accounting cycle, taking into account the need to confirm the reliability of a wide range of environmental, social and economic indicators.

In contrast to the international model, the convergent stakeholder model of accounting, reporting and auditing can be derived from the Global Sustainable Investment Alliance, in which the volume of assets held under the Responsible Investment Strategies in 2016 p. compared to 2014 increased by a quarter and amounted to 22.89 trillion USD (Global Sustainable Investment Review (2016)) [10].

The spread of the "green economy", which requires the implementation of responsible financing mechanisms, generates relevant requests for accounting models and information forming systems and its independent verification. Support at the level of supranational organizations, primarily the United Nations and its structural units, the doctrine of sustainable development and the fight against climate change, embodied in the goals of sustainable development, lead to the need for changes in accounting models and concepts.

The adoption of investment decisions, taking into account the criteria for sustainable development, requires appropriate accounting and analytical support, which is produced within a convergent model that takes into account not only the approaches and methodology for harmonizing financial, but also non-financial reporting, in order to ensure comprehensive transparency of the activities of companies.

Thus, the determinants of the formation of this model are [12]:

1) convergence of international and national systems of professional accounting, reporting and auditing standards in order to ensure transparency of companies and disclosure of information on the management of all types of capital;;

2 ) integration of accounting and analytical support of decision-making processes by stakeholders of companies at all levels.

The second hypothesis of the study relates to the implementation of the context of sustainable development into the modern accounting model, in view of the spread of responsible investment practices, the green economy, the adoption of corporate social reporting standards and the intensification of corporate sector interaction with a wide range of stakeholders (local communities, nonprofit organizations, government structures, consumers, etc.). The generation of new, previously untapped requests from stakeholders, which relate to the formation of not only economic added value, but also the company's ability to manage social and natural capital, creates additional requirements for the transparency of reporting companies and the emergence of its non-financial (integrated) formats.

The determinants studied should be supplemented by the theoretical basis for the formation of a convergent stakeholder model of accounting, reporting and auditing.

At the level of concepts of accounting, reporting, auditing, convergence is manifested as interpenetration and complementarity of traditional concepts oriented to reflect the financial and economic activities of organizations, and the concept of accounting, reporting, audit in a sustainable development, which, in turn, focuses on the full coverage of all aspects activity and gives impetus to the consideration of the ability of organizations to accumulate, use and reproduce all kinds of resources (capitals) during the creation of value for stakeholders.

The selection of indicators, which specifies the information requests of stakeholders in accordance with the most significant themes of sustainable development, has been proposed to be implemented taking into account the following requirements: a universal, integrated and 
interrelated nature and coverage of three dimensions of sustainable development; voluntary character; long-term orientation; openness, inclusiveness, transparency and opportunity for all; human-centricity and gender sensitivity, concentration on human rights and vulnerable groups of the population.

\section{CONCLUSIONS}

The analysis of the theoretical detail describing the nature of the relations between the level of disclosure of information in the reporting on the sustainable development of companies, traditional financial indicators and indicators of responsible investment, testifies pluralism of approaches to its study and modeling. In our opinion, the key areas that need improvement are: the choice of an array of traditional financial indices and responsible investment indices that cover not only the leading financial markets in different regions of the world (the USA, Europe, Asia), but also the fundamental criteria for sustainable development and disclosure information about companies of constituent indicators that more fully meet the goals of sustainable development; the formation of the methodology of the research data from the standpoint of the feasibility of using the hypothesis of effective markets or the hypothesis of fractal markets as an instrument that explains the work of traditional financial markets and responsible investment markets, as well as checking the relations between disclosure of reporting on sustainable development and the information efficiency of financial markets in terms of hypotheses of effective markets; the extension of the research period from the time of the emergence of key indicators of responsible investment to date, as well as from the position of information efficiency of financial markets of the precrisis, crisis and post-crisis period in the context of geographic regions with developed financial markets and developing markets.

\section{References:}

1. Braam, G. \& Peeters, R. (2018), Corporate sustainability performance and assurance on sustainability reports: Diffusion of accounting practices in the realm of sustainable development. Corporate Social Responsibility and Environmental Management, 25(2), 164-181. https:// doi.org/10.1002/csr.1447

2. Evans, S. Vladimirova, D. Holgado, M. Van Fossen, K. Yang, M. Silva, E. A. \& Barlow, C. Y. (2017), Business model innovation for sustainability: Towards a unified perspective for creation of sustainable business models. Business Strategy and the Environment, 26(5), 597-608. URL: https://onlinelibrary.wiley.com/doi/full/10.1002/ bse. 1939

3. Geissdoerfer, M. Savaget, P. \& Evans, S. (2017), The Cambridge business model innovation process. Procedia Manufacturing, 8, 262-269. URL: https://doi.org/10.1016/ j.promfg.2017.02.033

4. Gil'orme, T. Ryzhyk, Y. \& Yaresko, A. (2016), Formation of the mechanism of energy efficiency management on the basis of 'predator-prey'concept. Problems of development modern science: Theory and practice: Collection of scientific articles. EDEX, Madrid, Espa?a, 107-110. URL: http:// conf.at.ua/27.07.2016_ispanija.pdf\# page $=107$

5. Gil'orme, T. (2016), Formation of mechanism of promoting energy efficiency technologies on the basis of stakeholder concept.

Intelligence XIX, (1), 90-97. URL: http://www.intellect21.nuft.org.ua/journal/2016/2016 1/12.pdf

6. Global Sustainable Investment $\bar{R}$ eview 2016. URL. http://www.gsialliance.org/wp-content/uploads/2017/03/ GSIR Review2016.F.pdf

7. Hilorme, T. (2016), Human capital assets as a specific intangible asset of the enterprise. University Economic Bulletin, (29 (1)), 73-80. URL: https://www.ceeol.com/ search/article-detail? $\mathrm{id}=461536$
8. Hilorme, T. Nazarenko, I. Okulicz-Kozaryn, W. Getman, O. \& Drobyazko, S. (2018), Innovative model of economic behavior of agents in the sphere of energy conservation. Academy of Entrepreneurship Journal, Volume 24, Issue 3, 2018. URL: https://www.abacademies.org/journals/month-september-year-2018-vol-24issue-3-journal-aej-past-issue.html

9. Marcucci, E. Le Pira, M. Gatta, V. Inturri, G. Ignaccolo, M. \& Pluchino, A. (2017), Simulating participatory urban freight transport policy-making: Accounting for heterogeneous stakeholders' preferences and interaction effects. Transportation Research Part E: Logistics and Transportation Review, 103, 69-86. https:// doi.org/10.1016/j.tre.2017.04.006

10. Tetiana, H. Chorna M. Karpenko L. Milyavskiy, M. \& Drobyazko, S. (2018), Innovative model of enterprises personnel incentives evaluation. Academy of Strategic Management Journal. Volume 17, Issue 3, 2018 URL: https:/ /www.abacademies.org/journals/month-june-year-2018vol-17-issue-3-journal-asmj-past-issue.html

11. Tetiana, H. Karpenko, L. Fedoruk, O. Shevchenko, I. \& Drobyazko, S. (2018), Innovative methods of performance evaluation of energy efficiency project. Academy of Strategic Management Journal, 17(2), 112110. URL: https://www.abacademies.org/articles/ innovative-methods-of-performance-evaluation-ofenergy-efficiency-projects-7067.html

Yang, M. Evans, S. Vladimirova, D. \& Rana, P. (2017), Value uncaptured perspective for sustainable business model innovation. Journal of Cleaner Production, 140, 1794-1804. https://doi.org/10.1016/j.jclepro.2016.07.102

Стаття надійшла до редакиії 12.03.2019 p. www. dy.nayka.com.ua

Електронне фахове видання

\section{ДЕРЖАВНЕ МУПАВЛЛННЯ удосконалення та розвиток}

Виходить 12 разів на рік
Видання включено до переліку
наукових фахових видань України 3 ДЕРЖАВНОГО УПРАВЛІННЯ
e-mail: economy_2008@ukr.net
тел.: (044) 223-26-28
(044) $458-10-73$ 